\title{
REVISTAMARACANAN
}

Artigos

\section{Imagens de uma República infantil: Angelo Agostini nas revistas $O$ Malho e $O$ Tico-Tico}

\author{
A young republic in children's images: \\ Angelo Agostini's works in $\mathrm{O}$ Malho and $\mathrm{O}$ Tico-Tico
}

\author{
Roberta Ferreira Gonçalves \\ Universidade Federal Fluminense \\ robertagon@yahoo.com.br \\ Ivan Lima Gomes \\ Universidade Estadual de Goiás \\ igomes2@gmail.com
}

\begin{abstract}
Resumo: O presente artigo procura refletir sobre a atuação de Angelo Agostini em duas grandes publicações da Primeira República: as revistas $O$ Malho e O Tico-Tico. Na primeira, uma revista ilustrada de variedades, conhecida pelas caricaturas e pela crítica política, Agostini encontrou um espaço significativo para um veterano do traço, pouco integrado às novas possibilidades técnicas. Na segunda, uma revista ilustrada voltada à infância, desenvolveu uma nova linguagem que tinha os futuros cidadãos republicanos como foco de sua verve crítica. Este artigo tem como objetivo pensar as diferentes facetas de um artista celebrado, mas pouco estudado em suas últimas atuações profissionais durante a República. O material de Agostini sobre os conflitos do século XX e a infância pode contribuir para nuançar sua memória, bem como desvendar uma personalidade complexa e mutante de um artista que viveu intensamente as mudanças políticas de seu tempo.
\end{abstract}

Palavras-chave: Imprensa; Narrativas visuais; Caricatura; Infância.

Abstract: We discuss Angelo Agostini's activities during the Brazilian First Republic in two relevant magazines, $O$ Malho and $O$ Tico-Tico. The former is an illustrated magazine known for its cartoons and political criticism, to which Agostini contributed as a veteran artist, not always aware of new techniques. The latter is an illustrated magazine for kids, which demanded from Agostini a new language in order to present Republican themes to future republican citizens. Agostini's late years form a relevant part of his work, which is not acknowledged among scholars. Agostini's material on the XXth Century conflicts and childhood provides a new perspective on his figure, contributing to the unraveling of a complex and mutant personality who was actively engaged in the changes of Brazilian society of the period.

Keywords: Press; Visual narratives; Cartoon; Childhood. 
Os últimos anos da vida de Angelo Agostini contrastam com a glória e o reconhecimento alcançados pelo autor a partir de acontecimentos como a Abolição da Escravidão (1888) e a queda da Monarquia (1889). ${ }^{1}$ Conhecido por sua atuação combativa na Revista Illustrada, onde seu traço detalhista e satírico expunha os maus-tratos aos cativos e o atraso das instituições monárquicas, ${ }^{2}$ Agostini logo se tornaria um dos símbolos da luta contra a escravidão ao lado de intelectuais e jornalistas de peso como José do Patrocínio e Joaquim Nabuco. Passados os anos de euforia inicial, a partir da mudança de regime, Agostini é celebrado como um veterano na arte do traço numa imprensa que passava por sérias transformações técnicas e editoriais que, por vezes, chocavam-se com sua formação profissional anterior.

Seus últimos trabalhos foram publicados nas revistas ilustradas O Malho e O Tico-Tico. Curiosamente, ambos - autor e trabalhos - acabaram esquecidos na memória daqueles que se empenharam em construir Agostini como um artista vigoroso e crítico no mundo das artes gráficas brasileiras. Sua atuação profissional no século XX foi praticamente esquecida por biógrafos e estudiosos, por vezes mais empenhados em deixar marcada sua memória como um herói do abolicionismo. Vale destacar a ressalva de Balaban, pesquisador preocupado com a construção de uma memória para Agostini ligada à luta contra a escravidão, para quem a disseminação dessa memória está muito mais relacionada a uma tentativa de eleger lideranças brancas para a luta pela abolição do que ao reconhecimento de uma postura ativa do artista no movimento. ${ }^{3}$

Podemos desdobrar tal análise e apontar que essa leitura canônica produzida sobre o artista ítalo-brasileiro termina por encerrá-lo num conjunto de temas e abordagens em detrimento de outros também desenvolvidos por Agostini ao longo de sua carreira. Nesse sentido, a imagem de um homem que passara a desenhar para crianças, numa imprensa que começa a se massificar, contrasta com aquela que o estabelece como figura marcante de uma imprensa mais opinativa e artesanal. ${ }^{4}$ Nas duas revistas, Agostini precisou abandonar uma linguagem mais satírica e politizada em troca de um tom mais leve e celebratório. Também procurou explorar recursos mais modernos e adequados ao tipo de impressão desenvolvido nas oficinas da empresa, ${ }^{5}$ tentando conciliar novas técnicas ao seu traço já característico.

\footnotetext{
* Este artigo é resultado dos desdobramentos de pesquisa financiada pela CAPES.

1 BALABAN, Marcelo. Poeta do lápis: a trajetória de Angelo Agostini no Brasil Imperial - São Paulo e Rio de Janeiro (1864-1888). Tese (Doutorado em História). Universidade Estadual de Campinas, Campinas, SP, 2005.

2 Mais informações sobre a Revista Illustrada ver em RIBEIRO, Marcus Tadeu Daniel. "Revista Illustrada (1876-1989): síntese de uma época". In: LUSTOSA, Isabel (Org.). Agostini: obra, paixão e arte do italiano que desenhou o Brasil (1843-1910). Rio de Janeiro: Fundação Casa de Rui Barbosa, 2014. p. 3771.

3 BALABAN, Marcelo. Op. cit., 2005. p. 19.

4 MARTINS, Ana Luiza. "Imprensa em tempos de Império". In: LUCA, Tania Regina; MARTINS, Ana Luiza. História da Imprensa no Brasil. São Paulo: Contexto, 2008. p. 45-80.

5 MARINGONI, Gilberto. Angelo Agostini: a imprensa ilustrada da Corte à Capital Federal, 1864-1910. São Paulo: Devir, 2011. p. 217.
} 
Na imprensa infantil, Agostini encontrou espaço para abordar temas como cidadania, progresso e república de forma distinta ao discurso usualmente empregado com os adultos. Falando às novas gerações já nascidas sob o signo da República, e ainda que através de breves e esparsas contribuições, também pôde consolidar uma imagem de si mesmo tanto como conhecedor das mazelas promovidas pela escravidão quanto como defensor de uma república liberal e moderna. Esses trabalhos voltados à infância apontam para um personagem complexo que procurou atender às diversas demandas sociais e culturais do seu tempo, para além das canonizações estabelecidas sobre sua figura ao longo da história. ${ }^{6}$

\section{Celebrando a República: Angelo Agostini n'O Malho}

Em 1904, Angelo Agostini é anunciado como o mais novo colaborador artístico da revista O Malho, compondo um time de artistas como Isaltino Barbosa, A. Cruz, Alfredo Candido, Malaguti, Falstaff e J. Arthur. ${ }^{7}$ Desde o fim da revista Dom Quixote em 1903 - e com uma rápida passagem pela Gazeta de Notícias -, Agostini se esforçava para encontrar lugar numa imprensa em intensa transformação técnica. Porém, sua popularidade parecia não acompanhar o reconhecimento outrora obtido. N'O Malho, seu nome é apresentado junto aos nomes de artistas menos experientes na imprensa, sem maiores destaques. Ainda que sua presença certamente garantisse peso à publicação que buscava consolidar-se no mercado, é possível perceber que Agostini não encontrava ali o mesmo espaço e a mesma autonomia com que estava acostumado a trabalhar em publicações nas quais atuara até então. Agostini agora fazia parte de uma equipe de jornalistas e artistas integrados num projeto editorial bem definido.

Isso, porém, não significa dizer que Agostini era apenas mais um nome entre o grande número de caricaturistas que figuravam nas páginas d'O Malho. Mesmo que anunciado em meio a artistas de menor envergadura, é Agostini quem assina a charge apresentada logo abaixo do anúncio do novo corpo artístico, o que demonstra o interesse da publicação em destacar seu trabalho, situando-o para o público como paradigma daquilo que se poderia esperar dos caricaturistas da revista. No futuro, porém, raras foram as ocasiões em que suas ilustrações chegaram à capa, e a charge política parece não ter sido sua especialidade na revista. Não obstante tenha produzido ilustrações ironizando as mudanças e o cotidiano da cidade-capital, n'O Malho o lápis de Agostini voltou-se para a elaboração de representações visuais de cunho patriótico.

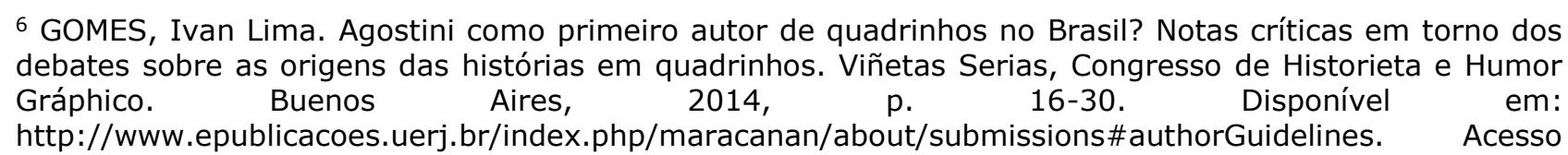
em: $10 / 10 / 15$.

7 O Malho, 1904, 28 de maio, n. 89, ano III. 
Por ser um artista de tradição acadêmica, com um traço preciso e preocupado em retratar cenas e pessoas com riqueza de detalhes ${ }^{8}$ - técnica distinta da caricatura da imprensa do século $X X$, que privilegiava a distorção fisionômica,$-{ }^{9}$ Agostini ganhou espaço ilustre na revista para elaborar grandes painéis envolvendo os conflitos do seu tempo. Através de seu lápis, em página inteira, eram retratados episódios da Guerra Russo-Japonesa, confrontos entre populares, militares e polícia na Revolta da Vacina, ou grandes desastres, como a catástrofe com a balsa General Slocum, que vitimou milhares de pessoas, em 1904. ${ }^{10}$ As imagens criadas pelo artista não eram mero registro jornalístico; antes, funcionavam como grandes reflexões sobre eventos marcantes no tempo presente. Em comum, havia a atenção aos conflitos que inauguravam o século e pareciam mostrar as "ambiguidades do progresso", na expressão de Costa e Schwarcz. ${ }^{11}$

As datas comemorativas da revista por ocasião de seu centésimo número ${ }^{12}$ e de seu aniversário ${ }^{13}$ também foram ilustradas por Agostini. A riqueza de detalhes que parecia trazer de volta a memória a ser celebrada se mostrava integrada aos objetivos da publicação. Essas imagens construídas pelo artista eram geralmente coloridas, algo raro na publicação até meados de 1905, quando a aquisição de um maquinário mais moderno permitiu seu desenvolvimento técnico. ${ }^{14}$ Para além da capa, a utilização da cor era uma estratégia utilizada a fim de chamar a atenção do público para determinado conteúdo e pode ser vista como um reconhecimento d'O Malho à importância das ilustrações produzidas por Agostini.

A Agostini também coube ilustrar as homenagens prestadas à República, por meio de seus heróis e símbolos, como em uma ilustração de página inteira publicada na edição de número 91, em tributo ao Almirante Barroso. ${ }^{15}$ Ela contava com um grande retrato do personagem, cujas façanhas estavam simbolizadas em seu peito repleto de condecorações militares. Abaixo, a reprodução de uma cena da famosa Batalha do Riachuelo, ocorrida em junho de 1865, durante a Guerra do Paraguai, seguida de legenda que ressalta a condição heroica do personagem através de diversos adjetivos: "O bravo almirante Barroso, o audaz marinheiro que, com a velha fragata $<<$ Amazonas $>>$, traçou na história do heroismo uma das páginas de mais intenso brilho: - o combate naval de Riachuelo". É importante apontar que a Guerra do Paraguai, além de ter se tornado um importante evento para a memória da

\footnotetext{
8 Maiores informações sobre as características da charge na imprensa ilustrada do século XIX ver TEIXEIRA, Luiz Guilherme Sodré. O traço como texto: a história da charge no Rio de Janeiro de 1860 a 1930. Papéis Avulsos. No 38. Rio de Janeiro: Edições Fundação Casa de Rui Barbosa, 2001. p. 13.

9 MARINGONI, Gilberto. Op. cit. p. 25.

10 O Malho, 30 de julho de 1904, n. 98, p. 10

11 COSTA, A.; SCHWARCZ, L. 1890-1914: no tempo das certeza. São Paulo: Companhia das Letras, 2000. p. 10.

12 O Malho, 13 de agosto de 1904, n. 100, ano III

13 O Malho, 17 de setembro de 1904, n. 105, ano III.

14 A aquisição de novas rotativas Marinoni e a reformulação do material tipográfico foram anunciadas na edição n. 153, de 19/08/1905 da revista O Malho.

15 O Malho, 1904, 11/06/1904, n. 91, ano III. p. 10.
} 
República, ${ }^{16}$ já fazia parte do repertório gráfico de Agostini construído desde o Império, tendo sido decisivo para sedimentar seu posicionamento político na imprensa diante do Estado Imperial. ${ }^{17}$

Um pouco depois, a técnica de Agostini prestaria homenagem a um símbolo universal da República. ${ }^{18}$ Em ilustração de página inteira, o artista cria uma alegoria em comemoração à proclamação da Declaração dos Direitos do Homem e do Cidadão. Na referida imagem, Agostini usa livremente diversos símbolos da Revolução Francesa tornados caros à República, como a Marianne e o barrete frígio. ${ }^{19}$ Essas imagens, frequentes na imprensa republicana desde fins do século XIX, eram conhecidas e largamente utilizadas por Agostini. Chama a atenção a presença de uma cena de guerra no canto direito do painel, com a população em armas e canhões; como contraponto, no alto da imagem, é representada a Bastilha, símbolo do autoritarismo monárquico e da explosão da revolução. A mensagem de Agostini parece indicar que a República e seus bens valiosos - como a Declaração dos Direitos do Homem e do Cidadão - não se estabeleceram sem conflitos e enfrentamentos. A operação do caricaturista em rememorar a luta pela liberdade ocorrida na França, num periódico brasileiro, termina por inserir a recém-proclamada República na mesma linhagem histórica de lutas e transformações, atribuindo-Ihe responsabilidade. Pessoas lutaram e morreram pela República e por seus direitos; para que o novo regime se estabeleça de forma sólida no país tal trajetória não pode ser esquecida, mesmo que a queda da Monarquia no país tenha assumido trajetória própria.

Em outra imagem, Agostini elabora um painel de página inteira em celebração à Proclamação da República, utilizando seu traço para prestar homenagens a um tema cívico. ${ }^{20}$ Dessa vez, porém, a mesma técnica refinada e cuidadosa de Agostini serve a outros objetivos, na medida em que aponta uma ironia ao representar D. Pedro II. Na parte inferior da página, um jovem soldado agita a bandeira da República enquanto a população festeja o cortejo do Exército, em frente ao quartel-general, quando da Proclamação da República. Acima, Agostini representa a partida da família imperial e a morte do monarca. Tais representações circundam a figura de D. Pedro II, localizada no centro do painel e retratada de maneira mais detalhista em meio a nuvens. A imagem presta tributo não apenas à República, mas ao monarca e à sua morte, como a sinalizar que o imperador é uma figura importante de um tempo que já passou e merece ser rememorado em função do futuro promissor que o Brasil teria em outro regime, a República. Passados quinze anos do fim da monarquia, é possível que a imagem desgastada do monarca já estivesse sendo superada. Se, durante o regime monárquico, Pedro II fora o

\footnotetext{
16 Adriana Barreto de Souza discute a existência de uma batalha de memórias de personagens da Guerra do Paraguai na produção de livros didáticos de história durante a Primeira República. SOUZA, Adriana Barreto. "Um herói para a juventude: o duque de Caxias nas biografias e livros didáticos". In: ROCHA, Aparecida et al. A escrita da história escolar: memória e historiografia. Rio de Janeiro: Editora FGV, 2009. p. $127-148$.

17 BALABAN, Marcelo.Op. cit., p. 56.

18 O malho, 1904, n. 96, 16/07/1904, n. 96, ano III. p. 23.

19 Ver: CARVALHO, José Murilo de. Formação das Almas: o imaginário da República no Brasil. São Paulo: Companhia das Letras, 1990.

20 O Malho, 1904, 12/11/1904, n. 113, ano III. p. 16.
} 
foco de suas críticas, na República, outros eram os problemas a serem enfrentados. O caráter jocoso com que Agostini retratou o imperador no passado não era mais necessário. ${ }^{21}$.

Para além dos atributos artísticos de Agostini, bastante apropriados à ornamentação e grandeza típica das representações de temas cívicos e comemorativos, o reconhecimento obtido em vida como crítico da monarquia foi um elemento importante para orientar sua escolha como ilustrador desses eventos. No entanto, a República também continha suas ambiguidades, na medida em que, de uma forma ou de outra, era marcada por conflitos violentos. Apesar de sua inserção na revista como ilustrador de efemérides, Agostini soube muito bem utilizar o espaço obtido para a crítica autoral. Pôde também se aventurar por outros caminhos inexplorados por ele até então. A imprensa infantil foi um desses novos trajetos inaugurados por um Agostini já maduro. Antes, porém, de aventurar-se nesse novo campo como um dos fundadores da revista O Tico-Tico, O Malho foi um espaço de experimentação de Agostini para a elaboração de narrativas infantis.

\section{Uma nova linguagem para as futuras gerações: da revista $O$ Malho para $O$ Tico-Tico}

A primeira experiência de Agostini na produção de conteúdo infantil ocorreu ainda $n^{\prime} O$ Malho, com a publicação de uma tira cômica intitulada "Por causa de um cachorro", publicada em duas partes, nos números 109 e 110. Desde seu lançamento, em 1902, a revista O Malho publicava contos infantis, mas, somente em 1904, passou a investir em outras linguagens voltadas para a infância, como as tiras cômicas, possivelmente influenciadas pelos quadrinhos que davam seus primeiros passos na imprensa norte-americana. ${ }^{22}$ No caso d'O Malho, tais materiais carregavam lições morais aliando-as ao humor, peça importante na conquista do leitor infantil. Elas eram geralmente apresentadas em preto e branco, com traço simples e ocupavam no máximo meia página. A tira cômica criada por Agostini, no entanto, seguiu o padrão técnico e estilístico de suas publicações na revista, ocupando toda a página do periódico com cenas mais minuciosas e coloridas.

"Por causa de um cachorro" conta a história dos meninos Oswaldo e Zezinho surpreendidos por uma matilha que os seguia enquanto caminhavam tranquilamente em direção ao colégio. Assustados, os meninos correram até que a carrocinha da Prefeitura, presenciando a cena, laçou os cães. Um dos animais, no entanto, pertencia a D. Quitéria, que vivia na vizinhança e estava disposta a lutar para retomar o seu cão. ${ }^{23}$ No número seguinte, a história avança para a disputa entre D. Quitéria e o laçador da carrocinha. A confusão instaurada fez com que os cachorros fugissem. O laçador manteve o cão de D. Quitéria nas

\footnotetext{
${ }^{21}$ Sobre as representações de Agostini a respeito de Pedro II ver: SCHWARCZ, Lilia K. Moritz. "D. Pedro Banana: o imperador nas caricaturas". In: LUSTOSA, Isabel. Op. cit. p. 247-268.

22 GORDON, Ian. Comic strips and consumer culture, 1890-1945. Washingnton/London: Smithsonian Institution, 1998.

23 O Malho, 15 de outubro de 1904, n. 109, ano III.
} 
mãos e iniciou-se uma disputa: enquanto a mulher segurava a cabeça, o laçador puxava as patas traseiras do cão. O resultado é assustador: o corpo do animal se parte e a sua cabeça, retida nas mãos de D. Quitéria, levanta gritos de horror na multidão. O final trágico é reforçado pela legenda do último quadro: "D. Quitéria apertava contra o peito a cabeça de seu cão e dizia: - Meu Pacholla! Eu queria-te como se fosses meu filho!". ${ }^{24}$

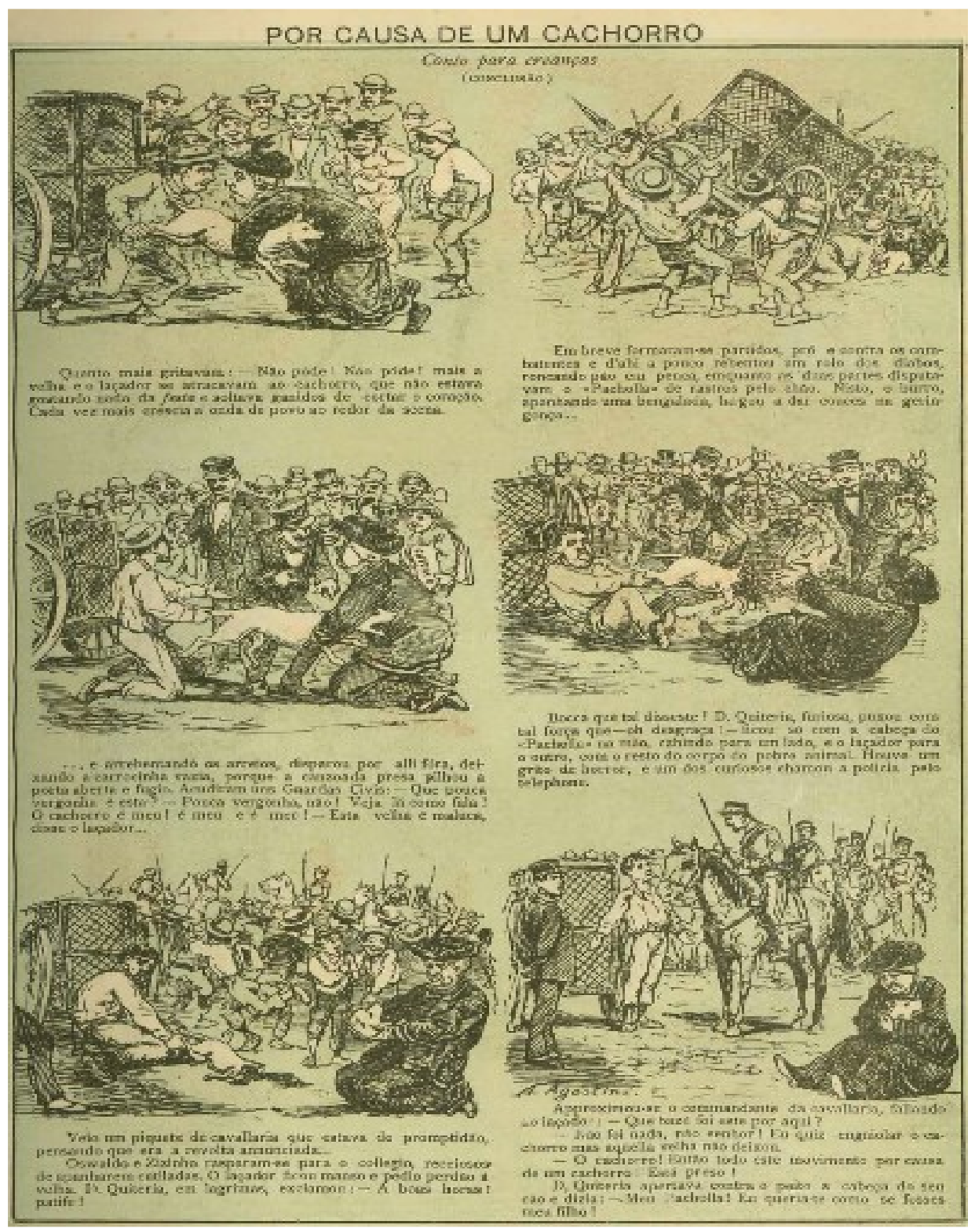

Figura 1: O Malho. Rio de Janeiro, 22/10/1904, n. 110.

Acervo da Fundação Casa de Rui Barbosa.

Apesar de ser "um conto para creanças", a história criada e ilustrada por Agostini abusa do grotesco. Ainda que a tragédia e o grotesco tenham sido elementos frequentemente

24 O Malho, 22 de outubro de 1904, n 110, ano III. 
utilizados como recurso pedagógico nas tiras infantis d'O Malho, ${ }^{25} \mathrm{a}$ imagem perturbadora do cão despedaçado nas mãos de sua dona parece não ter agradado o público leitor, de acordo com Rosa. ${ }^{26}$ Talvez o tratamento - entre o trágico e o cômico - dado a um acontecimento cotidiano ocorrido na capital da República tenha sido um pouco demais para seus leitores. Curiosamente, essa foi a primeira e última investida de Agostini para o público infantil d'O Malho, que ganhava cada vez mais espaço na revista pelas mãos de artistas como Leônidas e J. Carlos.

No entanto, mesmo diante da descontinuidade da relação de Agostini com os leitores infantis, sua participação na revista O Tico-Tico não foi dispensada. Lançada em novembro de 1905, a revista infantil foi criada a partir de um processo de segmentação de impressos iniciado com a compra de novas rotativas para as oficinas d'O Malho. O novo título contou com a presença do artista nos seus dois primeiros anos de existência. A pedido de Luís Bartolomeu de Souza e Silva, dono e editor das publicações d'O Malho, Agostini elaborou o logotipo que estamparia o cabeçalho da revista. Desenhado sobre pedra litográfica, foi substituído, entre 1917 e 1918, por um novo logotipo elaborado pelo desenhista Max Yantok. Ainda em 1918, porém, o trabalho de Agostini retorna adaptado e permanece até 1923, quando J. Carlos reformula todo o projeto gráfico da revista e inaugura uma nova identidade visual para a publicação. ${ }^{27}$

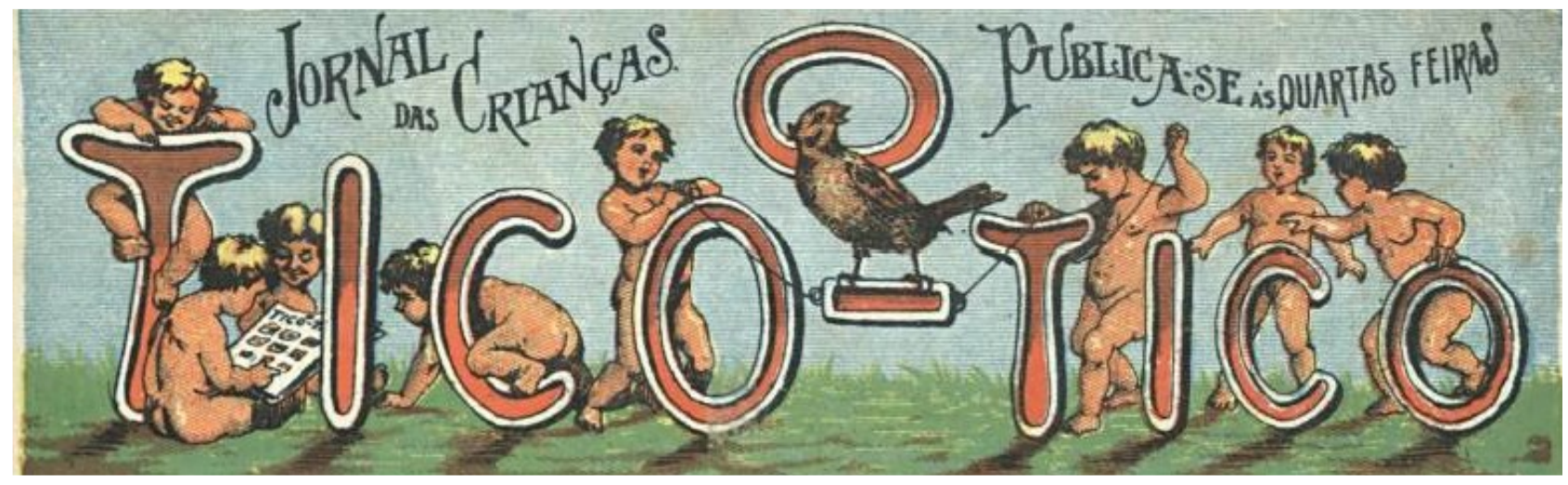

Figura 2: O Tico-Tico. Rio de Janeiro, 11/10/1905, n. 1. O cabeçalho da revista, assinado por Agostini, foi mantido até 1917.

Acervo da Hemeroteca Digital da Biblioteca Nacional.

O cabeçalho criado por Agostini passa uma mensagem de pureza e inocência. As crianças, retratadas como espécies de querubins, se divertem por entre as letras que formam

25 GONÇALVES, Roberta Ferreira. A escola em brincadeiras: intelectuais e ideias na criação da revista $O$ Tico-Tico. Dissertação de mestrado em história, Universidade do Estado do Rio de Janeiro, Rio de JaneiroRJ, 2011. p. 39-43.

26 ROSA, Zita de Paula. O Tico-Tico: meio século de ação recreativa e pedagógica. Bragança Paulista: Edusf, 2002. p. 16.

27 MERLO, Maria Cristina. O Tico-Tico. Um marco nas histórias em quadrinhos no Brasil (1905-1962). Dissertação (Mestrado em Comunicação Social). Escola de Comunicação e Arte, USP, 2003. p. 27-28. 
o título da revista. O pássaro faz referência ao próprio título da publicação, ainda que existam divergências sobre quais seriam as origens desse título. ${ }^{28} \mathrm{~A}$ imagem criada pelo artista aponta para uma determinada ideia de infância, tida como uma fase ingênua da vida, que necessita ser cuidada e guiada em seu desenvolvimento. Tal representação da infância acompanhará outros trabalhos de Agostini n'O Tico-Tico.

Agostini também foi responsável por desenvolver as capas das festas de fim de ano, onde o ideal de infância destacado no logotipo é reafirmado. ${ }^{29}$ Além disso, os editores prometeram a publicação das Aventuras de Zé Caipora a partir do segundo número, ${ }^{30}$ mas a história nunca teve continuidade na revista O Tico-Tico. Publicada inicialmente na Revista Illustrada e depois na Dom Quixote, essa série de aventuras fora retomada por Agostini na revista O Malho, desde outubro de $1905 .{ }^{31}$ No entanto, a série se encerrou em dezembro do ano seguinte, ${ }^{32}$ quando Agostini termina suas atividades $n^{\prime} O$ Malho e n'O Tico-Tico. Não obstante seu caráter visual - o que fez com que alguns a estabelecessem de forma controversa como a primeira história em quadrinhos no mundo 33 - e o reconhecimento de Agostini como autor de narrativas ilustradas que se aproximava do perfil gráfico proposto na revista infantil, Aventuras do Zé Caipora não era exatamente uma publicação destinada ao público infantil do século $X X$, o que talvez justifique que sua publicação n'O Tico-Tico não tenha se concretizado.

Dois trabalhos de Agostini n'O Tico-Tico merecem destaque. O primeiro foi publicado na edição de número $5^{34}$ e era uma versão ilustrada da História de Pai João, narrativa folclórica presente desde os anos finais da escravidão brasileira que fala de um escravo que se torna feitor. Sua perversidade e violência no trato com os demais escravos da fazenda faz com que estes peçam o retorno do feitor branco, considerado mais humano com os cativos. Ao fim da história, Pai João acaba no tronco, açoitado pelos próprios escravos. Antes, porém, de se iniciar a história, Agostini acrescenta um pequeno texto que serve de explicação à narrativa subsequente:

\footnotetext{
Os meninos sabem que o Brazil já teve escravos? Infelizmente é uma verdade. O escravo não era pessoa, era cousa; vendia-se como se fosse um animal irracional. Comprava-se gente como se compra burros. Faziase trabalhar essa gente durante muitos annos, toda a vida, sem Ihe pagar um vintém e quasi sempre debaixo de muita pancada, empregando-se ainda instrumentos de supplicio, como o tronco, a gargalheira, e outros. Nas fazendas os escravos habitavam em senzalas ou casebres de páo a pique e telha vã, onde viviam todos misturados, dormindo pelo chão. Os feitores tomavam conta dessa gente escrava e de seu serviço. Quando eram bons a cousa ia bem; mas a maior parte eram ferozes, e a vida do

28 LIMA, Herman. História da Caricatura no Brasil. v. 1. Rio de Janeiro: José Olympio, 1963. p. 158.

29 As capas especiais de Natal e Ano Novo foram publicadas, respectivamente, em 27/12/1905, n. 12, e 10/01/1906, n. 14.

30 O Tico-Tico, 18/10/1905, n. 2, ano I.

31 O Malho, 28/10/1905, n. 163, ano IV. p. 19-20.

32 O Malho, 15/12/1906, n. 222, ano V. p. 16.

33 CARDOSO, Athos Eichler. "Nhô-Quim e Zé Caipora". In: LUSTOSA, Isabel. Op. cit. p. 319.

34 O TiCo-TiCo, $8 / 11 / 1905$, n. 5, ano I.
} 
escravo era tão cheia de torturas, que muitos preferiam morrer e suicidavam-se. Felizmente, a 13 de maio de 1888 acabou-se com essa desgraça, abolindo-se a escravidão. A Historia de Pai João, que é verdadeira, é um pequeno panno de amostra dessa triste época. ${ }^{35}$

A escravidão é apresentada como uma "triste época" da história do Brasil, superada após a Abolição da Escravidão, em 1888. Em tal regime reinava a "pancada" e a objetificação da vida humana, ao ponto de escravos se tornarem animais irracionais. A situação de extrema alienação seria levada ao nível do absurdo na narrativa do Pai João, em que um escravo assume as funções sociais de um homem branco. Porém, sem a devida instrução e já marcado por uma vida brutalizada, Pai João torna-se um violento feitor, para insatisfação dos próprios escravos.

A História do Pai João pode ser entendida como um registro simbólico que expressa, de um lado, o racismo dos brancos e, de outro, uma espécie de vingança do negro, rompendo com a imagem do escravo submisso. ${ }^{36} \mathrm{Em}$ Agostini, a história assume contornos ambíguos. Ao mesmo tempo que critica a escravidão, aponta para os traumas que o regime imprimiria em sua população escrava, tornada violenta e brutalizada, sem capacidade de discernir sobre suas ações. Pai João é descrito como um "nêgo feiticero", ao passo que o feitor branco é o amigo dos escravos, cujo objetivo era apenas "organizar o serviço e augmentar a produção da fazenda". A escravidão imprimiria danos irreparáveis ao exercício da liberdade pela população negra.

Em todo caso, vale destacar que, se durante o Império a escravidão era uma das principais bandeiras de luta de Agostini, nos anos iniciais do século $X X$, outras questões assumem maior relevo. A atribuição positiva dada ao papel do trabalho na sociedade é ressaltada na figura do feitor na História do Pai João e foi uma das bandeiras defendidas em outro trabalho publicado n'O Tico-Tico, intitulado "A arte de formar brasileiros".

\section{A arte de formar brasileiros: lições de um veterano do traço aos futuros cidadãos da República}

Seção de vida relativamente breve na história de uma revista que sobreviveu mais de cinquenta anos, "A arte de formar brasileiros" durou dezoito números, mas foi marcante no início da revista $O$ Tico-Tico por se conciliar perfeitamente com os objetivos da publicação de "instruir e deliciar as crianças". ${ }^{37} \mathrm{O}$ objetivo da seção era levar lições de comportamento e civismo a pais e crianças e questionar aquilo que seria importante para uma nação que se pretendia grande.

\footnotetext{
35 Idem.

36 ABREU, Martha. "Outras histórias de Pai João: conflitos raciais, protesto escravo e irreverência sexual na poesia popular". Afro-Ásia. 31, 2004, p. 235-276. Disponível em: http://www.afroasia.ufba.br/pdf/31_11_outras.PDF. Acesso em: 02/11/2010.

37 O Tico-Tico, 11/10/1905, n. 1, ano I.
} 
Parece não haver consenso na bibliografia sobre a autoria da seção n'O Tico-Tico. Enquanto Cardoso e Maria Cristina Merlo afirmam apenas que a seção foi criada e escrita exclusivamente por Agostini, Hansen não o situa como o responsável por ela, apesar de seu nome constar como autor de ilustrações ao longo de, aproximadamente, metade do tempo de sua duração. Certamente, isso se deve ao fato de, a partir do terceiro número onde aparecia a seção, constar o pseudônimo de Tio José como o responsável pela "A Arte de Formar Brasileiros". 38 É possível perceber que outros ilustradores acompanham Agostini em desenhos produzidos para a seção, porém a autoria dos textos não é apresentada de forma clara aos leitores. Outro ponto que merece atenção e contribui para mais dúvidas se deve ao fato de ser prática recorrente na revista que seus ilustradores também assinassem as seções. Com isso, Agostini certamente teria assinado algumas das Artes de Formar Brasileiros.

Em todo caso, mais importante do que pretender estabelecer a autoria real e efetiva de "A Arte de Formar Brasileiros", importa mais o fato de que não é possível ignorar que, no mínimo, Agostini exerceu papel de referência entre aqueles diretamente envolvidos na sua produção - autores e leitores. Nos quadros de uma imprensa de massa que começava a ganhar corpo, isso aponta uma ampliação da "função-autor", contribuindo para trazer novos olhares aos debates centrados na excepcionalidade da figura de Agostini. ${ }^{39}$ Do Agostini da imprensa ilustrada do século XIX que assume a proa de todo o processo de produção jornalística de forma quase artesanal - da redação dos textos à impressão, passando pelas detalhadas ilustradas -, passamos a um Agostini que inspira e serve de referência a jovens artistas e leitores, que vai cedendo espaço às novas gerações, à medida que vai encerrando suas atividades na imprensa. A "Arte de Formar Brasileiros" foi o último trabalho de Agostini n'O Tico-Tico; em 1906, sairia da revista e também d'O Malho, vindo a falecer em 1910.

O papel de liderança exercido pelo artista pode ser identificado logo na estreia de "A Arte de formar brasileiros". Ocupando uma página inteira, no canto superior esquerdo, temos uma ilustração que apresenta a seção. Nela, encontra-se Angelo Agostini rodeado de crianças. Como se ele estivesse contando uma história, meninos e meninas olham atenciosos em sua direção, enquanto uma criança sentada no chão lê a revista $O$ Tico-Tico. O redator anuncia que seu objetivo seria escrever sobre "cousas que precisam saber os meninos que se querem tornar homens fortes - cousas úteis que os pais devem ensinar aos filhos - o que o menino deve saber para mais tarde vencer as difficuldades da vida". 40

\footnotetext{
38 O Tico-Tico, 13/06/1906, n. 63, ano II.

39 Para Foucault, a "função-autor" não se restringe à atribuição de autoria individual a um determinado trabalho, mas se relaciona igualmente com as formas de circulação e apropriação de um texto numa dada sociedade. FOUCAULT, Michel. Ditos e escritos: Estética - literatura e pintura, música e cinema. v. III. Rio de Janeiro: Forense Universitária, 2001. p. 264-298.

40 O Tico-Tico, 30/05/1906, n. 34, ano II.
} 


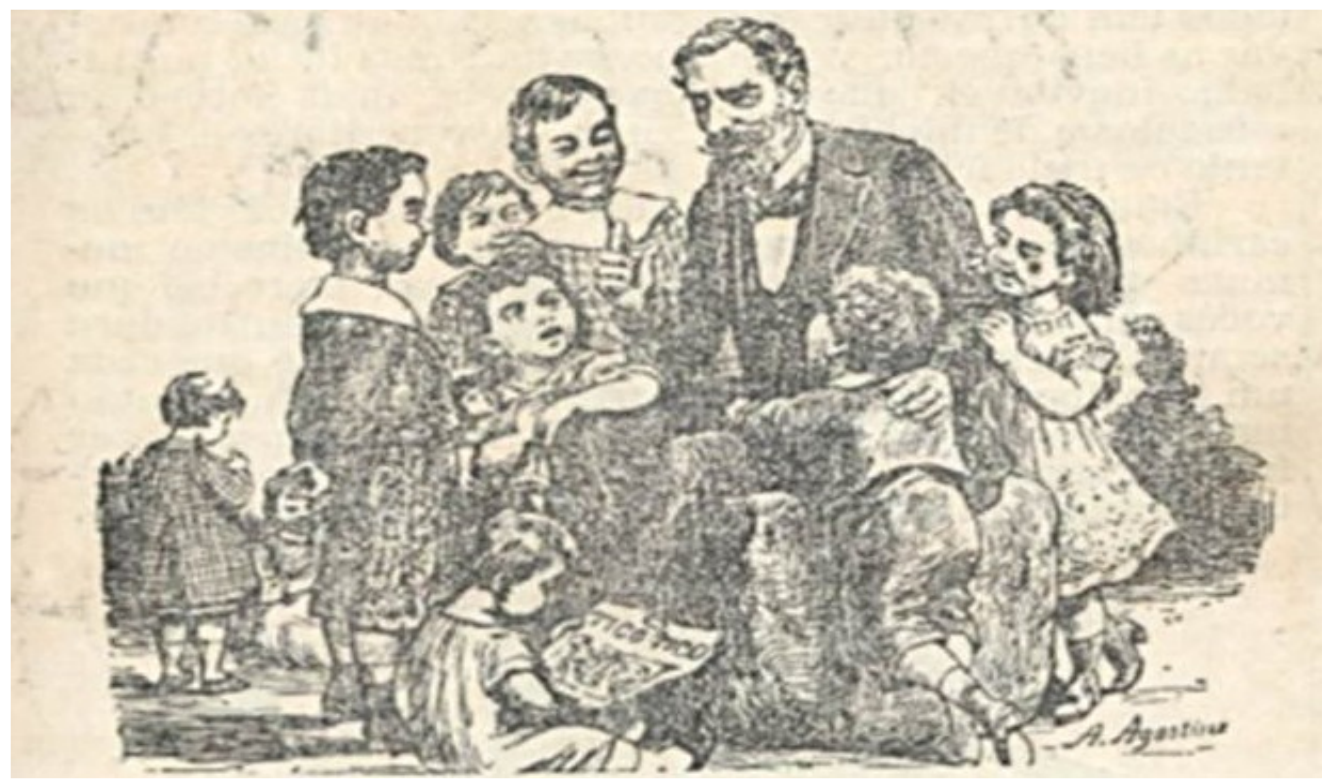

Figura 3: O Tico-Tico. Rio de Janeiro, 30/05/1906, n. 34. "A Arte de Formar Brasileiros".

Acervo Hemeroteca Digital, Biblioteca Nacional.

Nessas breves lições, a inspiração crítica de Agostini é apresentada em ensinamentos que dispensaram a linguagem da pilhéria, do chiste, da ironia, recorrentes na abordagem agostiniana até então. Ricamente ilustrada, a seção dialogava com as perspectivas de Agostini sobre as carências e potencialidades da nação e com o pensamento cívico e a literatura infantil da época. ${ }^{41}$ Ela também se destacava por mostrar uma faceta pouco conhecida de Angelo Agostini até então: com mais de sessenta anos, revelava-se um senhor amoroso e preocupado com a infância e os destinos da República a ser construída pelos futuros cidadãos/leitores d'O Tico-Tico.

A experiência de vida seria a guia naquelas breves lições, pois ele mesmo, sem ter ninguém que o guiasse e Ihe ensinasse o que deveria aprender, foi "obrigado a trabalhar muito, para conquistar os meios de sobrevivência". De certa forma, o texto parece descrever um pouco da vida de Agostini, na medida em que o artista veio da Itália para o Brasil ainda adolescente, acompanhado de sua mãe e logo começou a atuar na imprensa paulista. Para ele:

Enquanto se é criança a vida é risonha, vocês têm os carinhos de seus pais, nada preocupa os meninos e meninas que só pensam em folguedos, mas é preciso que vocês saibam desde já que, esse belo tempo não dura para sempre, chegando a uma certa idade é preciso que cada um trabalhe para si próprio e para a sua família, e então uma pessoa começa a encontrar dificuldades para fazer frente à inveja, à maldade e ao egoísmo dos outros, entretendo lucta terrível, cheia de embaraços e contrariedades. ${ }^{42}$

\footnotetext{
41 HANSEN, Patrícia. "A arte de formar brasileiros: um programa de educação cívica nas páginas da revista O Tico-Tico". In: MAGALDI, Ana Maria Bandeira de Mello; XAVIER, Libânia Nacif. Impressos e história da educação: usos e destinos. Rio de Janeiro: 7 Letras, 2008. p. 46.

42 O Tico-Tico, 30/05/1906, n. 34, ano II.
} 
Na passagem acima, é possível perceber que o autor cria uma oposição entre o mundo da criança, retratado como um "belo tempo", e o mundo do adulto, cheio de "inveja", "maldade" e "egoísmo" - sentimentos vividos por Agostini na própria pele, visto que se viu inclinado a sair do Brasil às vésperas da Proclamação da República, em meio à repercussão negativa de seu relacionamento amoroso.

As lições apresentadas na seção deveriam funcionar, nesse sentido, como uma forma de educar para o futuro e de preparar meninos e meninas para o mundo adulto, mais difícil e complexo que a infância. O futuro carrega incertezas e exige grande dedicação da criança: em outro artigo de Agostini, voltado para a saúde e o cuidado com o corpo, destaca-se que a prática de atividades físicas deveria ocorrer desde a infância. Apenas assim teríamos uma criança forte e apta a enfrentar os desafios do futuro. Conforme orienta Agostini: os meninos deveriam "fazer exercícios physicos moderados, gymnastica, jogos athleticos, como o foot-ball e o cricket, carruagem, equitação, corridas a pé e outros ${ }^{43 " .}$.

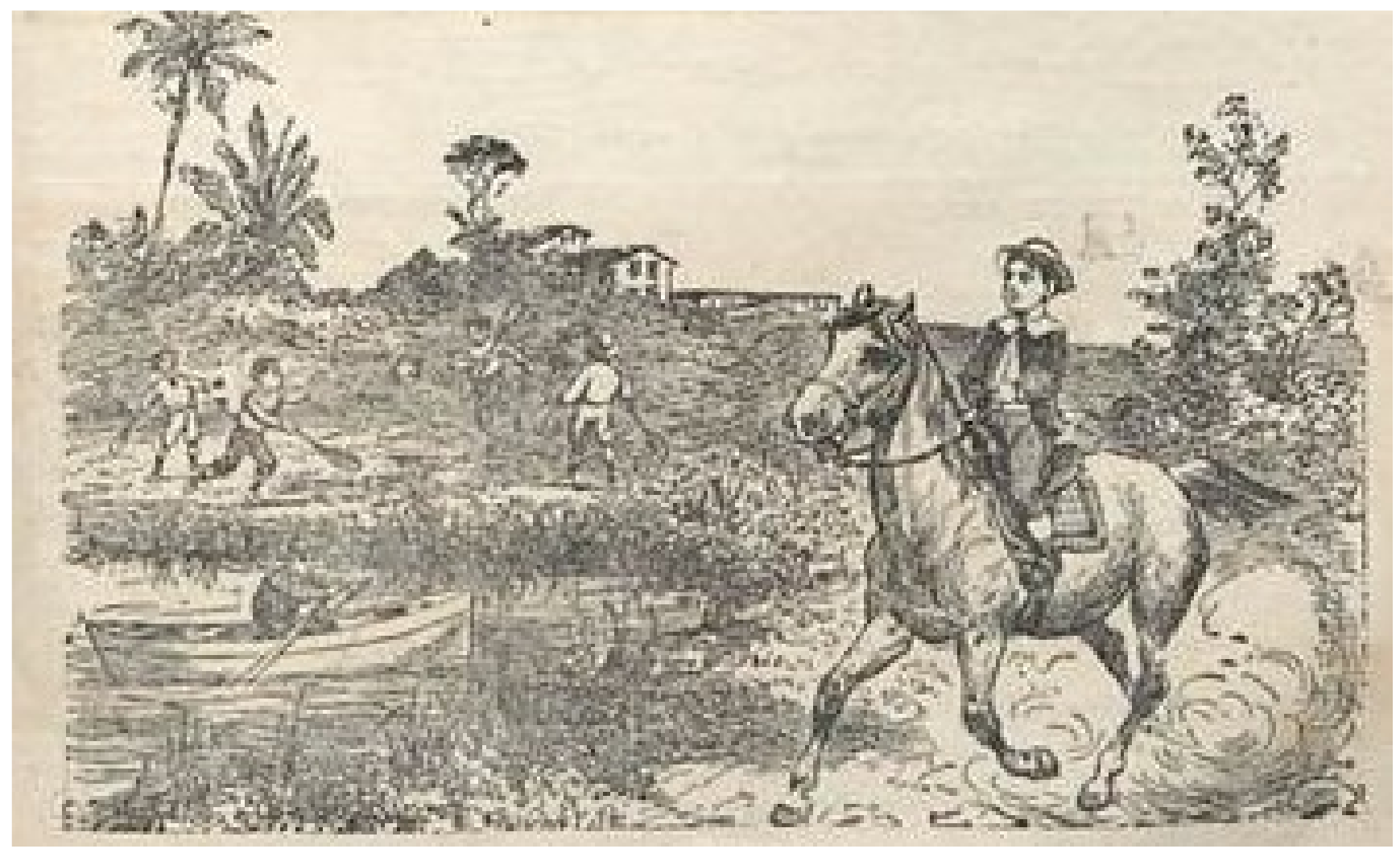

Figura 4: O Tico-Tico, 30/05/1906, n. 34, ano II.

Acervo da Hemeroteca Digital da Biblioteca Nacional.

A difusão de padrões de higiene e o cuidado com a saúde foram questões correntes e objeto de defesa de diversos intelectuais ao longo da Primeira República. Assim como a

43 O Tico-Tico, 30/05/1906, n. 34, ano II. 
Educação era vista como a saída para os males da nação, o asseio e o atendimento à saúde também faziam parte das expectativas republicanas. ${ }^{44}$

Em outra edição, será justamente a educação o tema da vez, compreendida a partir da sua relação com o trabalho. $\mathrm{O}$ argumento parte da ideia de que a criança deve estar atenta às suas habilidades desde cedo e procurar se informar sobre as diferentes profissões para não ser levada a escolhas ruins no futuro. Para Agostini, pais e familiares costumam orientar a vida profissional do filho, porém o fato determinante para a constituição do futuro cidadão deveria passar pelo estudo e o desenvolvimento de suas habilidades. Predominava aqui uma perspectiva prática sobre a Educação e o trabalho:

Antes de escolher uma carreira é preciso aprender umas tantas cousas que sempre são úteis; servem em qualquer situação para ajudar a nossa vida, isto é, independente de qualquer profissão; é indispensável a quem quer ser homem notavel, estar preparado para fazer qualquer trabalho que garanta a subsistência. ${ }^{45}$

A subsistência na vida adulta é vista no texto como o objetivo mais importante da construção de uma profissão e essencial na orientação dos estudos dos jovens. A educação, nessa perspectiva, deveria ser orientada para a vida prática, até porque, para o autor, esse homem do futuro deve estar consciente de seu papel na família e diante de sua pátria desde a infância, "contribuindo para a sua riqueza e engrandecimento". ${ }^{46}$ De forma complementar, ele defende que, "cada criança é uma força, é uma vontade, é um elemento poderoso de trabalho, de progresso e de grandeza para o país". ${ }^{47}$

A partir de tal olhar sobre educação e trabalho e sua relação com potencialidades do homem e do país, segue-se uma crítica ao bacharelismo, que seria a "maior desgraça desse país". 48 O desejo generalizado de possuir um título de médico ou advogado seria um desperdício das forças produtivas do país e representariam um Brasil deixado no passado. Para o autor, profissões menos afamadas e, de preferência, práticas e técnicas, poderiam garantir o engrandecimento futuro da nação. Os meninos deveriam se preparar para a vida prática e para um país que, apesar de suas potencialidades, ainda caminhava a passos lentos em direção ao futuro:

\footnotetext{
Ha outras carreiras igualmente nobres, porque o trabalho é sempre honroso e o homem só merece respeito por seu próprio valor e não o cargo ou o emprego que tem.

No nosso país, onde tudo está por fazer, o commercio, a industria, a lavoura, as artes offerecem campo vasto para quem tiver aptidões, constância, força de vontade, e estiver preparado para a concurrência dos outros. A electricidade e a mecânica e muitas outras são carreiras de grande futuro, de modo que é para poder trabalhar em qualquer dessas

44 CARVALHO, Marta Maria Chagas de. "Quando a história da educação é a história da higienização das pessoas". In: FREITAS, Marco Cezar (Org.). História Social da Infância no Brasil. São Paulo: Cortez, 1997. p. 305-306.

45 O Tico-Tico, 6 /06/1906, n. 35.

46 Id.

47 O Tico-Tico, 1906, 13/06/1906, n. 36, ano II.

48 O Tico-Tico, 1906, 27/06/1906, n. 38, ano II.
} 
carreiras - que todo menino deve se ir preparando para ser um homem feliz. ${ }^{49}$

Na passagem acima, destaca-se uma analogia corrente na literatura cívico-pedagógica: a do Brasil compreendido como uma criança. ${ }^{50}$ Tal como no regime republicano recémproclamado que deveria levar o Brasil a superar as limitações do passado e a ingressar num mundo de novidades e desafios, a criança seria dotada de potencialidades que, se bem trabalhadas a favor do progresso, garantiriam felicidade e prosperidade no futuro. Bastante corrente no discurso republicano da época, o autor investe na narrativa das belezas e potencialidades do território brasileiro contrastando-a, no entanto, com o atraso e a pouca educação correntes até ali e com a determinação do povo em civilizá-lo. Acima de tudo, predomina a ideia de que o Brasil seria um país que só concretizaria seu potencial no futuro, assim como o menino leitor, cuja felicidade e segurança seriam obtidas apenas na maturidade, quando se tornasse um cidadão do futuro.

\section{Considerações finais}

A atenção a alguns dos trabalhos finais de Agostini, produzidos ao longo dos primeiros anos do século $\mathrm{XX}$, revela que estamos diante de um artista complexo. Para além das canonizações produzidas a partir de associações irrestritas a processos como Abolição da Escravidão e Proclamação da República, bem como a práticas culturais em certo nível até anacrônicas ao seu tempo, como é o caso dos quadrinhos, o que temos é um autor complexo e cioso da sua obra. Não obstante, procurou inserir-se ao seu modo em uma imprensa que se encontrava em transformação, já distinta daquela em que atuara durante as décadas finais do século XIX.

É sintomático que seus últimos trabalhos se direcionem às crianças, tidas como o futuro do Brasil. Para alguém como Agostini, ativo participante da derrocada do "antigo regime" monárquico, difundir novos padrões de comportamento, tidos como modernos e empreendedores, poderia ser uma forma de ajudar a construir a sociedade republicana. 0 futuro do país dependia do esforço individual e da superação das dificuldades e dos desafios colocados pelo passado e pelo presente.

Nem sempre evitando contradições e limites, o quadro que se desenha aponta para um paradoxo: ao mesmo tempo que a figura individual de Agostini parece desaparecer gradativamente do mercado de impressos, vai assumindo seu lugar o legado deixado pelo artista às gerações futuras; do autor individualizado ao autor que marca uma criação coletiva que supera e ultrapassa seu tempo, chegando novamente à memória produzida sobre si mesmo.

\footnotetext{
${ }^{49} I d$.

50 HANSEN, Patrícia Santos. Brasil um país novo: literatura cívico-pedagógica e a construção de um ideal de infância brasileira na Primeira República. Tese (Doutorado em História). Faculdade de Filosofia, Letras e Ciências Humanas, USP. São Paulo, 2007.
} 
Ivan Lima Gomes: Doutor em História pela Universidade Federal Fluminense, defendeu tese sobre quadrinhos no Brasil e no Chile relacionando-os à arte, ao mercado e à política. Desde 2010, é professor de Teoria e Metodologia da Universidade Estadual de Goiás - campus Uruaçu. Atualmente é Coordenador de Programas e Projetos da UEG.

Roberta Ferreira Gonçalves: Doutoranda em História pela Universidade Federal Fluminense, com bolsa concedida pela CAPES. Mestre em História Política pela Universidade do Estado do Rio de Janeiro, com bolsa concedida pela CAPES, produziu dissertação sobre intelectuais e ideias na criação da revista O Tico-Tico. 